\title{
The Spirit of Long March and the Ideological and Political Education in Higher Vocational Colleges: Based on the Introduction of Mao Zedong Thought and Theory of Socialism with Chinese Characteristics
}

\author{
Junjie Wang \\ School of Biological Resource and Food Engineering, Qujing Normal University, Qujing, China \\ jjwangcn@sina.com
}

Keywords: Spirit of Long March; Ideological and political theory Education; Higher vocational Colleges

\begin{abstract}
The Long March Spirit is important ideological and political education resource; it can play the function of Ideological and political education. The Ideological and political theory course is the main channel of the spirit integration into ideological and political education in Higher Vocational Colleges. By formulating the teaching objectives corresponding to the curriculum, activating the content of teaching and Making use of a variety of teaching methods, the Spirit of Long March integrates into The Course, they help to promote the effectiveness of ideological and political education in Higher Vocational Colleges.
\end{abstract}

\section{Introduction}

The connotation of the Long March spirit includes: 1)The interests of the whole people and the Chinese nation are above everything else;2)The firm revolutionary ideals and convictions, the spirit which Firmly believes that a just cause is bound to win;3)the spirit of Not being afraid of any difficulties and Sacrifice at all costs to save the nation and save the nation; 4)The spirit of adhering to independence, seeking truth from facts and proceeding from reality in all work;5) The spirit of taking the interests of the whole into account, observing strictly discipline and closely uniting ;6) The spirit of relying firmly on the masses of people. The spirit of the Long March is a vivid reflection of the revolutionary style of the Chinese Communist Party and the People's Army. It is the concentrated expression of the Chinese nation character. It is the highest embodiment of the national spirit centered on patriotism. The spirit of the Long March provides a strong power for Chinese revolution from victory to victory. As a kind of spiritual wealth, the spirit of the Long March has a strong vitality, and constantly integrates into the great cause of socialist construction and reform, It's important practical value manifests mainly in: 1) seeking truth from facts; 2) patriotism; 3) Contacting the masses; 4) upholding the party's leadership. In the paper, four aspects above are integrated into the introduction of Mao Zedong thought and theory of Socialism with Chinese Characteristics (hereinafter referred to as "introduction"). The author discusses the teaching of Ideological and Political Theory Course to enhance the effectiveness of Ideological and political education in Higher Vocational Colleges.

An investigation was conducted on 122 vocational college students, The content of which is based on:1) the overall understanding of the spirit of the Long March;2)the practice of the long march spirit in life. The findings are as follows:

Table 1 Higher Vocational College Students' overall understanding of the spirit of the Long March

\begin{tabular}{|l|c|c|}
\hline \multicolumn{1}{|c|}{ option } & subtotal & proportion \\
\hline A. Knowing very well & 22 & $21.57 \%$ \\
\hline B. knowing a little & 74 & $72.55 \%$ \\
\hline C. no knowing & 6 & $5.88 \%$ \\
\hline
\end{tabular}


Table 2 Higher Vocational College Students' practice of the long march spirit in life

\begin{tabular}{|l|c|c|}
\hline \multicolumn{1}{|c|}{ option } & subtotal & proportion \\
\hline A. often & 28 & $27.45 \%$ \\
\hline B. occasionally & 45 & $44.12 \%$ \\
\hline C. Seldom & 26 & $25.49 \%$ \\
\hline D. never & 3 & $2.94 \%$ \\
\hline
\end{tabular}

Through the investigation, we can find out: It is not enough for the students of higher vocational colleges to recognize overall the spirit of the Long March; It is necessary for higher vocational college students to strengthen education of the Long March spirit. For the Higher Vocational College students, the practical value of the spirit integrates into "the outline", which deepens the understanding of the spirit. This way promotes the development of Ideological and political education in Higher Vocational Colleges.

\section{With the Spirit of the Long March as the Center, Formulating the Teaching Objectives Corresponding to the Curriculum}

The Importance of Ideal and Belief. The spirit of the Long March is an important ideological weapon for the Chinese Communists, which leads Chinese revolution, construction and reform to victory Comrade Deng Xiaoping pointed out: Why do we have been able to struggle in a very difficult situation, to overcome the difficulties of the revolution and to win the revolution? Because we have ideal, it is the Marxist belief and communist belief. [1]The second generation of collective leadership of the party with Comrade Deng Xiaoping at its core, They commence on the "long march "of the great cause of socialism with Chinese characteristics. Comrade Xi Jinping has repeatedly stressed the importance of ideal and belief, and expressed in the language of the image, ideal and faith is the spirit of the Communist Party 'calcium', no ideal and belief and the lack of ideal and belief, the spirit will 'calcium deficiency', Will be 'rickets', and stressed that " The belief in Marxism and Socialism and Communism is the political soul of the Communists and the foundation to settle down.[2]The discourse demonstrates the important determination of the Chinese Communists to strengthen their ideal and belief, highlighting the political character and political superiority of the Chinese Communist Party.

Historical Stage of Ideal and Belief. Revolutionary ideal and belief is an important prerequisite and basis for realizing communist ideal and belief. 80 years ago, the Chinese Communist Party led the Red Army officers to carry out the Long March, the ideal and belief is to achieve the people's liberation and national freedom. At present, we have entered a new stage of building a well-off society in a comprehensive way. This is a new and great long march. It requires that the spirit of the Long March should be used as an important content in strengthening the construction of socialist spiritual civilization. The spirit of the Long March helps to establish firmly the core of socialism Value system around the people. The broad masses of party members, cadres and the people are inspired by the common ideals of socialism with Chinese characteristics. We must vigorously carry forward the national spirit with patriotism as the core and the spirit of the times with reform and innovation as the core, and constantly enhance the self-esteem, self-confidence and pride of the whole nation, constantly enhance the enterprising spirit of the whole society, develop courage and innovate. The people of all ethnic groups are united, and struggle to realize the great reju venation of the Chinese nation.

\section{Taking the Times of the Long March Spirit as the Clue, Activating the Content of Teaching}

Seeking the Truth of Facts is the Quintessence of the Long March Spirit. In the process of teaching, the teachers can combine "seeking the truth from the facts" with "ideological line and the essence of the theory". Before the Long March and the early Long March, The Party's line is out of China' s reality, It has brought huge losses for the Red Army and the revolutionary base. During the 
Long March, the Zunyi meeting is a concrete manifestation of the thought. In the meeting, the problems faced by the Party and the Red Army were analyzed, The Party corrected the error, and ultimately formed the correct the principle of route, the Red Army arrived successfully in northern Shanxi, so that the Chinese revolution turned the corner. The revolutionary practice proved that seeking the truth of facts is scientific and ideological line. The fourth chapter of the textbook is the theoretical achievement of the preliminary exploration on the socialist construction road. It is the correct application of the thinking of seeking truth from facts in the socialist construction. The Chinese Communist Party began to understand and deal with the socialist contradictions from the reality of China in the 1950s, and took the great journey of China's industrialization path. Linked to today's socialist modernization construction in China, in the fifth chapter, the basic stages of the socialist basic line and the basic program are the application of the thought. According to seeking the truth of facts, The Communist Party of China has formulated the task of social construction and the goal of economic construction. Socialism with Chinese characteristics has made remarkable achievements. The spirit of the Long March is constantly enriched and developed in the practice of revolution, construction and reform, full of vigor and vitality, and its main driving force is the implementation of the thinking of seeking truth from facts.

Patriotism is the Essence of the Long March. Patriotism is an important spiritual pillar of the Chinese nation. In order to fight for Japanese, The Communist Party of China led the Red Army to carry out the Long March. It helps to achieve the great independence and the liberation of the Chinese nation. The great revolutionary practice of the Long March cast a great spirit of the Long March, and patriotism was the meaning of the Long March. The Long March is an important node to realize the process of national rejuvenation. The patriotism contained in the spirit of the Long March is the spiritual impetus to realize the national renaissance. In the socialist modernization, the long march is the key to the realization of the national renaissance. In the new period, we still need patriotism to unite the people, gather strength for the prosperity of the country and the common prosperity of the people. The socialism with Chinese characteristics practice gives the spirit of the long march of the practical significance. Patriotism is the construction of the spiritual source of Socialism with Chinese Characteristics. Whether the Long March or a new era of building a well-off society, we all need the spiritual power of patriotism. Combined with the textbook of the ninth chapter: "to achieve complete reunification of the motherland theory", students deepen the understanding of the spirit of the Long March. The reunification of the motherland is an important manifestation of national interests. It is also a historical task of realizing the revival of the Chinese nation. Patriotism is an important ideological condition for realizing national reunification. The anti-Japanese war is to defend the national sovereignty and territorial integrity, its essence is to maintain national unity, which is now consistent with the national unity. Vigorously carrying forward patriotism is an important ideological guarantee to achieve national unity of the new "Long March"

Serving the People is the Nature of the Spirit of the Long March. The Long March of the Red Army can be successfully completed. It is related to the mass line of the Party. On the way of the Long March, the Chinese Communist Party and the Red Army are concerned with the masses. By establishing the regime and satisfying the demands of the masses won the masses support. The people supplied food and guidance for marching and fighting to the Red Army. The Long March is the practice of the party's mass line, and provides a practical basis for concluding the party's mass line. The mass line on the way to the long march is a vivid expression of the purpose of the Chinese Communist Party serving the people wholeheartedly. Linked to the first chapter of " the main content and the living soul of Mao Zedong Thought ". The practice of long march gestates the Long March spirit, the mass line is the sublime of the Long March, serving the people is the embodiment of the Chinese Communist Party mass line, The spirit of the Long March provides a rich theoretical support for the development of Mao Zedong Thought. In the period of the revolutionary war, especially during the Long March, the Chinese Communist Party, relying on the support of the people of all ethnic groups in the whole country, successfully completed the strategic transfer. The victory of the new-democratic revolution was well prepared. the masses support the Communist 
Party of China, because the Communist Party of China serves the people wholeheartedly and carries out the line of masses. In the period of reform and opening up construction of socialism with Chinese characteristics, we still inherited the spirit of the Long March in the service of the people, relying on the ideas of the masses of the people. At the same time, constantly we innovate the party's mass line, unite all levels, and expand the building of socialism with Chinese characteristics.

Upholding The membership of the Party is the core of the Long March spirit. The reality of the failure of the old democratic revolution called for the establishment of the Chinese Communist Party. As advanced party guided by Marxism, from the founding, she has taken the responsibility of anti-imperialist and anti-feudalism, and has gradually become the leader of the Chinese revolution. The Communist Party played a leading role in the long march ,the Long March not only saved the party, more importantly, exercised the Party. The Long March propagated the ideas of the Party, expanded the party's influence. They are the important reference of history and people choice to the Chinese Communist Party. Teachers connect the leadership of the Party with the textbook: Communist Party of China's ruling position is the history and the people's choice. The victory of the Long March is reason for the people and the history's choice to the Chinese Communist Party. the Chinese Communist Party through the Long March arrived in northern Shanxi, opened a new chapter in the Chinese revolution. In the sacred war of resistance of the Chinese nation, the Chinese Communist Party played the mainstay role. After the war of liberation, the Chinese Communist Party led the people of all ethnic groups in the country to finally win the victory of the new democratic revolution. The Communist Party of China is the leader of the new democratic revolution. During ten years of construction period and the construction of a new era of socialism with Chinese characteristics, the Chinese Communist Party is still the core of leadership, and achieved great achievements in reform and opening. The Communist Party of China is to struggle for a well-off society. The experience of historical development and the fruitful achievements of the reality show that the Communist Party of China is the core of the Chinese Communist Party's revolution, construction and reform. By adhering to the leadership of the Chinese Communist Party, there are the achievements of the new China and the achievements of reform and opening up. The Chinese Dreams in the Revival of Chinese Nation will be realized.

\section{Making use of a Variety of Teaching Methods to Increase the Long March Spiritual Education Effectiveness}

History Teaching Method is the Primary Way of Education in the Long March Spirit. The spirit of the Long March is the crystallization of the great revolutionary practice of the Chinese Communist Party. Revolutionary practice is the basis and premise of revolutionary thinking. The Long March of the Red Army occurred in the confrontation period between the Kuomintang and the Communist Party. Therefore, in the course of classroom teaching, the Chinese history of modern history, especially the history of Chinese revolution and the history of Chinese Communist Party becomes the important content of teaching. The reason and the significance of the Long March is sorted out and analyzed, so that students understand the Long March, it is rooted in the practice of China's new democratic revolution. By the pictures and images of the Long March, Teachers explain the historical events and historical figures of the Long March, and guide students to make an objective evaluation of it. Fresh historical facts and material is the practice soil of the Long March spirit, also is a strong proof on the importance of the spirit of the Long March.

The Topic Teaching Method is the Core Way of Education in the Long March Spirit. The spirit of the Long March not only has a heavy historical practice foundation, but also has a rich practical value. The present value of the Long March is the combination of history and reality. The thematic teaching method effectively realizes the times about the spirit of the Long March. The thematic teaching method can highlight the core role of the long march education and realize the actual connection with the present. In the teaching process, teachers can set the following topics, such as: "Long March and the party's ideological line"; "Long March and the new democratic revolution"; "Long March and socialism with Chinese characteristics"; "Long March and the Communist Party". By the theme of refining, the Long March spirit integrates into the teaching 
materials and the teaching processes. it helps to achieve the real transformation of the Long March spirit, and enriches the connotation of the spirit of the Long March. All have deepen students' understanding and application of the Long March spirit.

Playing the Role of Social Practice. The practical characteristics of vocational colleges determine the importance of practical teaching. Practical teaching is the supplementary and extension of classroom teaching. Reasonable and appropriate practice teaching is helpful to improve the effectiveness and pertinence of teaching. Practical teaching transforms abstract theory into vivid material instances, and is a good way to apply theory to solving practical problems. For the Long March, firstly, social practice can be designed for extracurricular visit to the Long March historical sites, the author lives in the region where the Red Army's the San Yuan Palace site is located passing through Yunnan during the Long March; Expansion of the Red Army base in Huizhi, Red Army crossing Jinsha River in Kunming, become practical teaching base. Secondly, Teachers lead students to open an extracurricular investigation, for example, to understand the reality of the history, requiring students to investigate, interview, or personally find the history of the Long March. Together with students, Teachers participate in the social investigation, complete the investigation report and show the results of the survey.

\section{Conclusions}

Long March spirit is a precious wealth. It is an important resource of ideological and political education. By formulating teaching objectives, activating of teaching content and making use of a variety of teaching methods, the spirit of the Long March organically integrates into the ideological and political theory courses, which is helpful to enhance the teaching effect of ideological and political theory course in higher vocational colleges. It strengthens the effectiveness and pertinence of the teaching of ideological and political theory. At the same time, the integration of the Long March spirit into the classroom of vocational colleges is conducive to propagating the spirit of the long march Spirit. The students in higher vocational colleges carry forward the contemporary value of the Long March spirit. All promote the development of ideological and political education in higher vocational colleges.

\section{References}

[1] X.P.Deng:Selected Works of Deng Xiaoping (volume third),People's publishing house, Beijing,1993, pp.111-113.

[2] Information on http://news.xinhuanet.com.

[3] J.P.Xi:The Governance of China,Foreign Language Press Co.Ltd,Beijing,2014.

[4] L.J.Sun,the Long March Spirit integration into the Ideological and Political Education, The History of Gambling (Theory), (2016 )No.11,pp.59-61.

[5] H.Q. Xu,The inspiration of the Long March spirit to the ideological and political education of contemporary college students, Western leather, (2016)No.16, pp.232-233.

[6] Z.Y. Bao,The spirit of the Long March of the ideological and political education function ,Journal of Liaoning Administration College, (2016)No.8, pp.76-79. 